\title{
Collective or individual titles? Conflict over tenure regularisation in a Kenyan informal settlement.
}

\begin{abstract}
Providing formal titles to residents in densely populated informal settlements without fuelling conflict or encouraging gentrification presents several challenges. It has been argued that, in some contexts, forms of collective tenure such as a Community Land Trust may help to overcome some of these problems. This paper analyses one attempt to legalise informal tenure arrangements, minimise relocation and prevent gentrification by introducing collective titling in an informal settlement in Nairobi. The paper demonstrates how attempts to build consensus on the most appropriate tenure system were deeply embedded in local conflicts between existing structure-owners (owners of shacks/buildings on land which is not theirs) and tenants. The state was unable to carry out the land reforms it had proposed - to protect the land user rights of all residents - because they implied a redistribution that was resisted by local elite actors. This paper argues that tenure reforms are shaped by contextspecific power relations; in this case the process was characterised by the implementers' need to maintain fragile agreements with local elites in order to avoid conflict. Tenure reforms are based on different ideas of whose rights should be recognised and competing claims are both negotiated through and shaped by the implementation process. Tenure reforms for contested land in informal settlements not only require technical mechanisms to prevent gentrification and displacement, but must reflect a serious consideration of local power relations and the capacity of the state to deal with conflicts arising from redistributive plans.
\end{abstract}

\section{Key words:}

Land; tenure; informal settlements; conflict; elites

\section{Acknowledgements}

I wish to thank all the community members, the Government of Kenya, the project donor and the United Nations. Without their openness and availability, this research would not have been possible. I am most indebted to Melanie Lombard and Carole Rakodi for their support and guidance throughout. I would like to thank the three anonymous reviewers and the editors of Urban Studies for their thoughtful comments and helpful suggestions.

\section{Funding}

This research was generously supported by the Irish Research Council for the Humanities and Social Sciences. 


\section{Collective or individual titles? Conflict over tenure regularisation in a Kenyan informal}

settlement.

\section{Introduction}

Providing security of tenure in densely populated informal settlements presents several challenges. Tenure based on individual land titling has quickly spread as the recommended solution to address the housing needs of the urban poor in cities of the global South, although the appropriateness of this form of tenure has been questioned (Musembi 2007; Durand-Lasserve and Royston 2002; Gilbert 2002; Payne, et al., 2009). As an alternative, collective forms of tenure are being increasingly advocated as an alternative way of achieving security of tenure for the urban poor and it has been recognised that they deserve more attention (Rolnik, 2013). However, the available analyses of the implementation of forms of collective tenure reviewed by Cabannes (2013) seldom address the internal dynamics of informal settlements and how these affect implementation.

Building upon Boone's (2007) framework for understanding 'visions of land reforms' in rural Sub-Saharan Africa and critical development studies, this paper contributes to the debates regarding alternative tenure approaches in the upgrading of informal settlements and the agency of different actors in the implementation of development interventions. It does so by exploring local politics regarding the choice of tenure in a settlement characterised by entrenched social divisions. The article adapts Boone's framework to make sense of the politicisation of land tenure relations, competing understandings of who is entitled to land, and related conflicts in urban areas.

Boone emphasises the centrality of land politics for state building arguing that, in rural subSaharan Africa, reforming land tenure implies a redefinition of the 'relationships between and within communities, and between communities and the state' (2007, p. 558). This 
argument links very well with the one put forward by Corbridge et al. (2005) in the rural context and reframed by Watson (2009) in the context of informal settlements, namely that such redefinitions are not simply imposed by state agents but are reshaped in the daily encounters between state and citizens. From this critical development studies perspective, power always implies 'struggle, negotiation and compromise' (Long, 2001, p. 185), and the state is conceptualised as 'bundles of everyday institutions and forms of rule' (Corbridge et al., 2005, p. 5) to be analysed through the various and complex encounters between state and citizens (Gupta, 1995). Corbridge et al. argue that it is through these multiple encounters between the state and citizens that development outcomes, much like the state itself, are co-produced (2005, p. 8).

The article explores how such encounters between government officers and citizens play out in a slum-upgrading project in the context of the key urban processes including: high levels of tenancy and class division between tenants and structure-owners; urban land and housing market dynamics linked to market displacement and gentrification; and the dangers posed to national political stability by urban violence. In particular, the article analyses how negotiations between project implementers and residents' leaders over the type of land tenure to be adopted transformed the implementation of the Kwa-maji Urban Development Project (KUDP) ${ }^{1}$, a slum-upgrading programme initiated in Nairobi during the aftermath of the worst violence that Kenya had seen since independence, generated by the disputed general election of December 2007. This violence claimed more than 1,100 victims nationwide, including some within Kwa-maji, and resulted in over 350,000 people being internally displaced (Government of Kenya, 2008). The initial reform scenario proposed by the implementers of the project in Kwa-maji was contested by local power holders, radically shaping implementation. As outlined by Watson (2009), the interfaces between the different

\footnotetext{
${ }^{1}$ Pseudonym
} 
rationalities of implementers and residents are 'shaped by the exercise of power' (p. 2270). State efforts and plans - in this case to reform land - are met and challenged by "target populations' in various and complex ways, and these responses in turn shape the nature of interventions' (p. 2270).

In Nairobi, as elsewhere, it has been suggested that projects based on individual titling, while benefiting those who receive titles, are likely to lead to gentrification, exacerbating the exclusion experienced by poor residents (Huchzermeyer, 2008). In addition, it is asserted that regularisation based on individual titling does not sufficiently take into account the reality in Nairobi's informal settlements, where there is conflict between residents who are socially divided into two main groups: structure-owners (people who own shacks/buildings on land which is mostly publicly owned); and tenants, who comprise $92 \%$ of the residents (Gulyani and Talukdar, 2008, p. 1921) but are likely to be displaced if regularisation involves individual titling and leads to rent increases. Development agencies have proposed collective tenure as an alternative solution.

This article seeks to understand a failed attempt to adopt collective tenure, an option regarded as capable of overcoming the shortcomings of upgrading based on individual titling, which in Nairobi (as elsewhere) has often led to gentrification, the process through which some local residents (usually the intended beneficiaries) benefit from the increased value of newly titled land whilst others cannot afford to continue living in the regularised settlement and are replaced by more affluent people. To legalise informal tenure arrangements, the KUDP attempted to introduce collective tenure, in the hope that this would reduce the need for residents to be relocated and prevent gentrification. It sought to benefit all residents, both structure-owners and tenants. However, in practice, the social division between structure-owners and tenants and their different interests played an 
important role in the negotiations over the desirable form of land tenure. The implementers' intention that the project should benefit all residents and avoid gentrification conflicted with the interests of the local elite of structure-owners, who wanted to be allocated land through individual titles. A technically viable solution, collective titling, turned out, in these fairly typical circumstances, to be politically infeasible.

The next section introduces the methodology and important considerations regarding the anonymity of the case. The third section presents Boone's framework and links it with relevant debates on titling, explaining the rationale for collective tenure in the context of Kenya. Looking at Nairobi's low-income housing market and various projects, the fourth section identifies the major concern of gentrification. The fifth section introduces the case study of the KUDP, while section six presents the negotiations around land tenure that occurred during the project preparation process. These are analysed via discussion of two significant events documented through participant observation and interviews: a planning workshop with residents' representatives and a meeting where major stakeholders (excluding community representatives) met to take stock of the process. The paper presents the voices and perspectives of different actors - in particular the implementing agencies and the local elite - to understand their motivations and strategies.

\section{Methodology}

This article is based on 16 months of ethnographic fieldwork (September 2009-December 2010). During this period, the author was a participant observer in meetings and events connected to the KUDP, and participated in the everyday life of the settlement and the implementation process. The article also draws on published analyses of informal settlements and slum-upgrading in Kenya, official documents and reports from the KUDP, and formal and informal interviews with a wide range of actors. The study adopts an actor- 
oriented approach to the study of development interventions (Long, 2001), in which a development project is viewed not as the linear implementation of planned actions with expected outcomes, but as 'an ongoing, socially-constructed, negotiated, experiential and meaning-creating process' (p. 25). In particular, it focuses on conflicts, which are studied at specific social interfaces where 'discontinuities based upon discrepancies in values, interests, knowledge and power' between different actors became salient (p. 243). Two significant interfaces were selected to investigate the interests of and exercise of power by the key actors involved.

The case study has been fully anonymised, including the names of the settlement and the key actors. This choice was made for multiple reasons. Firstly, the informers and interviewees were assured of anonymity. Moreover, many of the institutional actors were represented by a limited number of staff, who would be easily recognisable if the settlement were to be identified. Furthermore, the programme deals with one of the most problematic political issues in Kenya: the distribution of land. This issue consistently generates conflict and already, at the time of the fieldwork, two community leaders in the informal settlement under study had been violently killed. As of April 2015, subsequent phases of the programme are ongoing, and publication of the research could potentially lead to conflicts among the actors currently involved or be used to attack their professional reputation. While many other researchers have anonymised their work (e.g. Platteau, 2004), sometimes even concealing the country (Rossi, 2004), without affecting the relevance of the argument, I am aware of the limits that such a level of anonymity implies, particularly around facilitating debate and comparative work. 


\section{Reforming urban land tenure}

Looking at rural land in Sub-Saharan Africa, Boone (2007) presents two ideal types of land tenure regimes and three scenarios for land reform. The first regime is what she calls 'the communal regime', in which it is membership in a local community that confers land-use rights. State recognition of these arrangements strengthens 'local-level actors' and is based on the premise that people in a specific area are a 'natural community' (2007, p. 563-564). The second is 'the user rights regime', in which case state power is used to challenge preexisting rights to enforce a regime that effectively extends rights to those who are not part of the original local community, particularly in-migrants who would be excluded under a 'communal regime'.

Boone (2007) identifies three possible scenarios for land reforms. The first consists in reinforcing community rights by delegating land allocation powers to local neo-traditional authorities. In the second, state actors promote private property rights, aware that this may lead to land concentration. The third seeks to institutionalise user rights by registering and titling land in such a way as to stabilise the situation and protect current land users from dispossession.

In the context of Nairobi's informal settlements, the 'natural community' is not the 'ancestral community' but often, depending on the history of the settlement concerned, those who first settled the area in the colonial or post-colonial era. Talking of user rights in this context means recognising residents who moved into the settlement at various stages. Slum-upgrading programmes, such as the one under study, are based on the idea of benefiting households resident in the area at the time of the programme, by recognising and formalising their user rights. Boone shows how reforms that securitise 'existing land use rights' necessarily expropriate 'the rights of [some of] those who claim entitlements' (2007, 
p. 584). 'Expropriation' has been described as 'the most explosive dimension of the land tenure debate' (2007, p. 582), but such a redistributive process is very likely to create conflict. Boone predicts that,

In many parts of Africa, conflicts over land access are rife at the local level. Under such conditions, one cannot expect that securitization of user rights will promote or be accompanied by a smooth transition to democratic, community based land management (2007, p. 584-5).

Manji agrees, highlighting 'how conflicts at community level, ranging from mild resistance to outright opposition to a scheme, can impede implementation' (2001, p. 335). Where the capacity of the state to deal with such conflicts and implement radical reforms is limited, as in Africa, she argues that it is important 'to identify an altogether different set of actors in the reform process' $(2001$, p. 328). In the case of Communal Property Associations in South Africa, for example, the work of Meer in Elandskloof reveals the 'intensely political nature of implementing land reform... [in which] the seemingly technical task of drawing up a beneficiary list was stalled as a result of community conflict' (1999, p. 81). Meer concludes that the South African government's progressive Community Property Associations Act of 1996 failed 'to consider how prevailing community dynamics and values can and will reshape social equity policy goals' (1999, p. 82).

Options for land reforms are also strongly related to debates about the optimum way to grant security of tenure and about the effectiveness of individual titling. In his highly influential work, de Soto (2000) argued that, although the poor have many assets, they cannot use them as collateral to access credit and invest in business because they lack property titles. De Soto's ideas inspired a set of policies focusing on land titling (Gilbert, 2012), which have been widely adopted, although it is striking how such policies have been pursued with little evaluation of the empirical evidence and despite strong criticisms (Musembi, 2007; Durand-Lasserve and Royston, 2002; Marx 2009). However, it has 
increasingly been recognised that titling is not a panacea capable of solving all the problems of the urban poor and that implementation is problematic: it is costly for both land administration agencies and owners (Durand-Lasserve and Royston 2002, Gulyani and Bassett, 2007); insufficiently flexible to take account of different pre-existing land regimes (Payne et al., 2009); and does not improve access to formal credit (Musembi, 2007). After years of enthusiastic promotion of titling as the key strategy for ensuring security of tenure, to encourage investment and asset accumulation by the urban poor, global development institutions are slowly recognising that the evidence paints a more complex and problematic picture (see, for example, Buckley \& Kalarickal, 2006).

While there is substantial evidence that titling can increase security, there are also examples where it has reduced security. For instance, the enhanced value of titled land has also made it attractive to higher-income groups, and rents have often increased significantly following titling. Thus, in some circumstances titling has favoured processes of gentrification (Payne et al., 2009). Moreover, corruption in the process of issuing titles may lead to 'land grabbing', resulting in the politicisation of projects, with elites interfering in the allocation process in order to appropriate valuable land.

It is alleged that elite interference in land allocation has been particularly prevalent in Nairobi (Gulyani and Bassett, 2007, p. 493), where some informal settlements have enjoyed political protection for decades through various forms of local political patronage, resulting in their inhabitants having 'de facto tenure security', even without titles. However, in Nairobi as elsewhere, these informal social institutions have been eroded by continued urban growth and development, especially competition over land, weakening the tenure security sometimes enjoyed under informal arrangements (Rakodi, 2006). In particular, changes of policies and politicians have led to evictions and demolitions. As a result, 
residents of informal settlements often perceive the government as a perpetrator of violent and destructive interventions that undermine their livelihoods. In this context, in the discourses of many Kwa-maji residents as well as project staff, formal land titles were considered to be a prerequisite for achieving long-term security of tenure, despite the costly and complex processes involved.

In 1988, the German Technical Cooperation Agency (GTZ) and the Government of Kenya started the Small Town Development Project (STDP), with the intention of upgrading informal settlements in secondary towns by providing security of tenure. The thinking which underpinned this project was very much in line with de Soto's argument (1989): it was anticipated that security of tenure would enable residents to develop their houses, obtain access to credit, etc. The long-term objective was to enable local governments to tax formally owned properties to raise resources for developing local services and sustaining themselves. The idea was that local government, through a minimum intervention to legalise land ownership, could harness the efforts of residents themselves to improve conditions in informal settlements.

When the programme started, it was recognised that one of the major problems faced by previous projects had been gentrification. ${ }^{2}$ In the search for a solution that could avoid problems such as the immediate resale of upgraded properties, the high cost of individual titling, and legal constraints on the minimum plot size, the STDP programme looked to the US experience of Community Land Trusts, assessing how these could be adapted to the complex legal framework in Kenya (Bassett and Jacobs, 1997). A Community Land Trust,

\footnotetext{
${ }^{2}$ For instance, in the World Bank-funded Dandora Sites and Services Scheme in Nairobi, developed in the 1970s, most of the plots had been sold by the allottees and only $25 \%$ of the original beneficiaries remained in the allocated houses at the beginning of the 1990s (Ogero, et al., 1992 in Bassett and Jacobs, 1997, p. 217).
} 
briefly, is a community-based, democratically controlled organisation formed to acquire and hold land for the use of its members. Its defining characteristic is the splitting of ownership: individuals own houses, while the Trust owns the land upon which the houses sit in perpetuity, thereby removing it from the open market.

The model aims to prevent low-income residents from reselling their plots and resettling in another settlement, ensuring that increases in property value are enjoyed by the community and preventing gentrification (see Diacon et al. 2005 for more details on the model and Cabannes 2013 for a comprehensive analysis of existing case studies). In short, the objective of a Trust is to secure long-term access to better housing for the original poor residents (Bassett, 2007). Moreover, a Trust is intended to reduce the costs of acquiring land and facilitate the payment of taxes. Costs are reduced for members by the lower legal and administrative costs of processing a single title deed, and for local authorities because most of the work of subdivision and ownership transfers is undertaken by the Trust. In addition, because the Trust collects and forwards tax payments from its members, the cost of collection is reduced and revenue increased. According to UN-Habitat, the implementation of a Community Land Trust in one of the STDP areas was very successful and it was considered a 'best practice', although more cautious assessments point out that the 'success' was achieved in a relatively small settlement in a small town where there was little conflict over land (Bassett and Jacobs, 1997; Bassett, 2005).

Gentrification was clearly a danger in Kwa-maji, where infrastructure provided by the project had already led to increases in land values and the project implementers wanted to avoid quick resales of plots and the capture of rising land values by external investors. The conception of the project was strongly influenced by this Community Land Trust experience. Not only had important staff members of the Lead Government Agency (LGA) managing the 
KUDP previously worked in the STDP, but the donor was also guided by the idea of collective security of tenure inspired by the STDP approach and strongly advocated by local missionaries. 'Collective security of tenure' was inserted in the initial Concept Paper for the KUDP, although as will be seen, it was later contested.

\section{Land and tenancy in Nairobi's informal settlements}

The importance of land in Kenyan culture and history, and the inequality of its distribution, has made it the most important national political issue (Southall, 2005). Informal settlements started to emerge in Nairobi at the beginning of the twentieth century, when colonial policies discouraged the provision of public housing in order to restrict the influx of Africans to the urban area (K'Akumu and Olima, 2007). However, from the 1920s onwards, in some areas of Nairobi, the colonial administration granted Temporary Occupancy Licenses, as an alternative to permitting Africans to become permanent owners of urban land. Licensees were allowed to build temporary housing, which contributed to the development of informal settlements. After 1963, when Kenya became independent and movement restrictions within the country were removed, the growth of informal settlements was accelerated by migrants in search of employment in the capital. At the beginning of this century, government policy makers and the United Nations claimed that informal settlements hosted $55-60 \%$ of the city's population despite occupying less than $5 \%$ of its land (Syagga et al., 2001).

The Government of Kenya's response to informal settlements has changed over time, following a path similar to many other developing countries. In the 1960s and 1970s, the official policy was one of slum clearance through demolitions and evictions. In the 1970s, site and services schemes aimed to relocate slum-dwellers to plots provided with basic services (Bassett and Jacobs, 1997). While sites and services projects partially succeeded in 
meeting the demand for housing, demand has continually outstripped supply (Government of Kenya, 2004). The shortage of low cost land and houses led to corruption during the allocation of plots.

Moreover, building codes, which had been inherited from the British without being adapted to Kenya's culture, climate, resources and level of economic development (Tuts, 1996, p. 608), forced such projects to be planned for middle-income rather than low-income citizens. High building standards, coupled with policies of cost recovery from beneficiaries, which began in the 1970s, made the serviced plots unaffordable to many low income households, including many of the original allottees, who sold their plots (Campbell, 1990; Syagga et al., 2001). As a result of the continuing shortage of affordable plots and houses and the relatively high cost of those available, middle-class appropriation of housing projects that supposedly targeted the urban poor has been widespread (Huchzermeyer 2008).

The Government of Kenya has increasingly recognised that, in cooperation with their residents, informal settlements can be upgraded in situ. However, Huchzermeyer (2008) argues that, in the context of Nairobi's distorted urban housing market, targeted slumupgrading projects have not achieved their objectives. The application of relatively high building standards, not only in site and services schemes but also in in situ upgrading projects, has led to rent increases, forcing slum-dwellers to relinquish upgraded areas to richer people. ${ }^{3}$ Dafe (2009) concludes that, through its slum-upgrading projects, the Government has subsidised groups with higher incomes rather than the low-income beneficiaries identified in project documents.

\footnotetext{
${ }^{3}$ Such gentrification processes have been described by Mitullah (1992) in her case study of the Umoja Tenant Purchase Scheme, Huchzermeyer (2008) in the Kibera High Rise project of the early 1990s, and Ochieng (2007) in Pumwani, among other examples.
} 
Land allocation along ethnic lines has been a key instrument for building and maintaining political support in Kenya, where the central debate in land politics has been around whose rights should be recognised by the state, giving rise to challenges to the legitimacy of past land allocations. Kenya's land politics is thus a 'redistributive game that creates winners and losers' (Boone, 2012, p. 75), creating a significant nexus between land, politics and violence. The post-colonial state favoured the resettlement of non-indigenous ethnic communities in rural areas such as the Rift Valley for political gain. Elections in such contested areas are often understood in terms of the struggle of native ethnic communities to recover their 'lost' land (Boone 2012) and the post-election violence in 2008 had both ethnic and land-related dimensions. Post-election violence also occurred in Nairobi, where informal settlements have for a long time been used by politicians to establish reservoirs of votes through political patronage (Chege, 1981). However, in many informal settlements in the city, including Kwamaji, the violence was rooted in rivalries between ethnic groups represented by different candidates, rather than land issues per se (Rigon, 2013).

About half of the informal settlements in Nairobi are located on public land (Syagga et al., 2001). In most, structure-owners have been issued with Temporary Occupancy Licences or other informal permits by city councillors or chiefs ${ }^{4}$, even though neither are legally entitled to allocate land (Joireman, 2011) and their allocations can be challenged by the Ministry in charge of land administration. As a result, different land tenure regimes and various authorities claiming jurisdiction over land overlap and clash in the city's informal settlements (Leach, 2000, p. 205). The lack of an effective land management system, costly

\footnotetext{
${ }^{4}$ In Kenya, until the implementation of the 2010 constitution, an area Chief was an appointed representative of the government in a certain location. Chiefs had many powers and could implement their decisions through the administrative police under their command. This system of local government is referred to as the Provincial Administration, although its functions are changing with the implementation of the provisions in the new constitution.
} 
bureaucratic procedures, and unrealistic regulations, as well as patronage and corruption in land allocation, constrain poor people's formal access to land. These complex and varied dimensions of Nairobi's informal settlements contribute to explaining why a large majority of residents are tenants renting rooms from structure-owners who themselves have only temporary and quasi-legal tenure (Bassett and Jacobs, 1997).

The role and the extent of rental housing in cities of the global South varies greatly, depending on complex local economic, social, political and legal dynamics (Rakodi, 1995). While many landlords have living standards similar to those of their tenants (Kumar, 2011), there are also more exploitative situations in which large-scale landlordism produces huge profits (Amis, 1984). In some contexts, most of the residents of informal settlements have built shacks in which they live. However, as far back as the 1970s, Amis (1984) argued that conventional squatting was no longer happening in Nairobi, and that it was more appropriate to speak of 'unauthorized commercial housing development' (p. 89). In this sector, Amis found 'extremely high profitability' and 'a well-developed system of informal ownership and landlord-tenant relations' (1984, p. 87). Political connections were fundamental to accessing land and investing in the lucrative informal housing business. As a result, a study published in 2008 found that only $5 \%$ of the households in Nairobi's informal settlements were structure-owners, while 92\% were rent-paying tenants (Gulyani and Talukdar, 2008). A report commissioned by UN-Habitat and the Government of Kenya concluded: 'It would seem quite possible that unauthorised housing is the most lucrative investment in Kenya' (Syagga et al., 2002, p. 2). Nevertheless, the report's authors recognised that the situation varies across settlements and that in some cases a large number of the investors were also residents who 'lived at a level fairly similar to their tenants and demonstrated a keen interest in maintaining the community and improving it' (Syagga, et al., 2002, p. 6). As emerged from my interviews, such small-scale resident 
landlords have often invested in structures as an alternative to a pension scheme. They consider themselves to be legitimate owners and so regard slum-upgrading programmes, which deem their claims over the land to be illegitimate and place them as beneficiaries on equal terms with their tenants, as unacceptably expropriating their investment. In the 1990s, there was an important debate in Kenya around renaming 'landlords' as 'structureowners'. This terminological shift was in part intended to clarify that 'structure-owners' do not own the land, as well as being part of an attempt to push an agenda of tenants' rights (Huchzermeyer, 2008; Syagga et al., 2001).

Today, there is wide consensus amongst scholars coming from very different perspectives whether associated with mainstream organisations such as the World Bank (Gulyani and Talukdar, 2008), the Kenyan Government and the United Nations (Syagga et al., 2001), or more grassroots organisations such as the Centre for Housing Rights and Evictions (COHRE) (Huchzermeyer, 2008) - that limited slum-upgrading interventions based on titling and infrastructure installation may, in the context of Nairobi's housing market, fail to benefit many existing low-income residents and may instead foster gentrification and capture by other groups. As a result, new programmes have attempted to rethink tenure options to ensure that interventions facilitate the provision of secure tenure to all low-income groups living in informal settlements. It is in this context that the KUDP tried to deliver collective security of tenure through the establishment of a Community Land Trust, in order to strengthen the user rights of all residents through a collective legal title.

\section{The Kwa-maji social conflict and the KUDP}

Kwa-maji was created in the 1970 s as a settlement for people who had been evicted from informal settlements closer to the centre of Nairobi. The growth of the settlement was enabled by temporary licences distributed on the basis of ethnic affiliation and political 
patronage, managed by a committee composed of the area Chief, his assistants, local elders, and local representatives of the KANU party that had ruled Kenya for 40 years. Those who obtained temporary licences built structures in which they lived, with additional rooms that were rented out to newcomers arriving from the rural areas. This process created the main, and enduring, social division in the settlement - that between structure-owners and tenants - which has had a profound effect on subsequent development programmes. Since the 1970s, an informal market in structures monitored by a local committee has emerged, which has made it possible for more affluent people to buy structures. By the time the upgrading project was initiated in 2008, many tenants had been renting a shack in Kwa-maji for over 20 years.

In 2000, in a desperate attempt to be re-elected, the incumbent President Moi went to Kwamaji and promised to give the land to residents of the area. In 2001, after Moi's announcement, an NGO with the support of local government initiated a slum-upgrading project, in which it was planned that all the residents, including long-term tenants, would receive secure tenure of the land. However, the structure-owners immediately claimed the land through the courts. Although they eventually lost the court case, the project was abandoned as a direct result of their action. A more structured and better-funded second attempt at upgrading - the KUDP - started in the spring of 2008 , shortly after the postelection violence.

According to the project's own census in 2010, Kwa-maji housed 34,000 people. Project documents state that most of the households are poor and $70 \%$ of the population is under 30 years old. Residents live without basic services in structures made of temporary and recycled materials. The main economic activities in the area are based on trade, together 
with some small manufacturing enterprises. Significant unemployment and high levels of crime and violence were also identified.

The KUDP was funded by a bilateral donor for an initial period of two years, during which it was intended to improve the living conditions of Kwa-maji residents through the provision of secure tenure to all residents and the building of infrastructure, using a participatory and inclusive planning process. The project was implemented by the LGA with technical support from a UN agency. As emerged from my research interviews, conversations, and analysis of documents, the first priority of the Kenyan government officials called on to implement the project with limited departmental capacity and restricted project resources, was to avoid any further violence. In other words, they identified the need to ensure that the project did not create additional conflict, which would not only have been unacceptable to the donor, but with which the government could not have coped. This was no easy objective to fulfil, considering that the programme intended to allocate land - the most delicate political issue - while at the same time, following the approach of the STDP which inspired the project in Kwa-maji, fostering a community-led process and minimising government intervention.

At the beginning of the project in 2008 , the land was owned by the Government, while the shacks/buildings belonged to structure-owners. The census of the area conducted by the project staff in 2010 revealed that about $19 \%$ of the households living in the area were resident structure-owners while $81 \%$ were tenants. It also showed that over half of all the structure-owners, who own just over half of the structures, were resident outside the settlement. The tenants were classified as either long-term tenants (those who had lived in Kwa-maji for more than 10 years) (36\% of all households) or short-term tenants (those who had lived in Kwa-maji for less than 10 years) (45\%). The importance of this distinction will 
become clear when we turn to the negotiations around the political issue of deciding to whom and how to allocate land.

In accordance with the project governance structure agreed by the Government of Kenya and the donor, decisions were taken through a participatory process involving residents, who were represented by an elected Residents' Committee, and guided by a Steering Committee comprised of three members of the Residents' Committee and representatives of relevant Government Ministries, the City Council, local missionaries, the UN, and the bilateral donor, and led by a representative of the LGA. Despite being a minority of residents, the structure-owners were politically organised and had already demonstrated their capacity to resist actions they perceived to be against their interests, through their court action to block the previous slum-upgrading attempt, described above. At the outset of the KUDP project, they resisted the proposed process of community elections for members of the Residents' Committee and only participated after having negotiated with project implementers a methodology for elections (forming lines in front of each candidate) and the composition of the committee in their favour. These concessions enabled structureowners (mostly resident but also absentee) to capture a strong majority in the 48 member Residents' Committee (Rigon, 2014). Project implementers saw the election of a Residents' Committee as a pragmatic mechanism for fulfilling the project's policy aims with regard to community participation, but in practice, the elections formalised the pre-existing social organisation and power structure (Rigon, 2014).

It is important to briefly mention some of the reasons (explored in more detail in Rigon 2014) for tenants' inability to struggle for more equitable representation in the Committee and later to articulate a unified voice to defend their interests during the processes analysed in the following sections. Open challenges to structure-owners' interests put tenants in a 
very difficult position, because they can be evicted at short notice and without reason. A large proportion of the tenant households in the settlement were female-headed (mostly single mothers and their children) and would have been severely affected by a sudden eviction. In this situation, many tenants establish patronage relations with their structureowners, for example often supporting the political interests of the latter. Moreover, compared with structure-owners, who expect upgrading to have an impact on their assets and source of income, poor tenants have little incentive to put their limited time and resources into a complex and uncertain struggle over land ownership. The next section will show how, as a result, (mostly resident) structure-owners, who dominated the structures of community governance, shaped the debate over security of tenure in order to defend their own interests.

\section{Negotiating tenure}

This section explores how tenure was negotiated during the initial planning process of the KUDP. It does so by analysing two critical social interfaces where conflicting interests amongst different actors were discussed. These interfaces were identified in the course of the fieldwork because of their significant role in influencing the KUDP's conversation around security of tenure. The first was a two-day planning workshop held in February 2010, during which the contentious issue of land tenure was discussed by government officials and residents' leaders. The second was a roundtable discussion in March 2010, during which the project implementers expressed their concerns about the power of the structure-owning elite and the risk of gentrification. A sample of the negotiations is presented below, to give voice to the actors and portray their own analysis of the process. This is complemented by extracts from interviews and informed by findings from the fieldwork as a whole. 
The key issue faced by the KUDP was undoubtedly the political question of land allocation: to whom to grant this scarce resource, in an area where land had already generated conflict. Everyone involved in the project was aware of the fundamental importance and sensitivity of security of tenure. The Government therefore sought to obtain agreement with 'the community', as represented by the Residents' Committee, on the best way to achieve secure tenure.

The initial KUDP proposal, put together by the LGA and the donor with technical support from a UN Agency, ${ }^{5}$ was for 'collective security of tenure', which was seen to have three main advantages. First, as outlined above, collective tenure is thought to prevent the resale of land, speculation and consequent gentrification (Bassett, 2005), in other words, protecting 'the community' from market forces. Second, it provides one single land title for a large group, thereby costing less than issuing a title to each beneficiary. Finally, a single title is thought to facilitate compliance with planning standards and building regulations because, while the main communal title must respect the by-laws, the smaller portions assigned to individual households are not subject to these restrictions. In addition, it was thought that collective ownership could potentially facilitate both the construction of multi-storey buildings, allowing higher densities, and the creation of cooperatives to enable saving and provide access to credit. Although the project implementers preferred the establishment of a Community Land Trust, sectional titles ${ }^{6}$ were also considered as an alternative type of collective tenure.

\footnotetext{
${ }^{5}$ The proposal was prepared with the technical support of a UN agency and approved by the Government of Kenya and the donor.

${ }^{6}$ Through sectional titles, individuals own a part of the land together with others. This is the title used for cooperatives, but also by those who buy an apartment within a larger building.
} 
In this proposal, all the residents - structure-owners and tenants - were identified as intended beneficiaries. However, the constitution of the Residents' Committee, which was drawn up by its members and the LGA shortly after its members had been elected, identified all structure-owners as the primary beneficiaries, followed by tenants who had lived in the settlement for more than 10 years. In addition, in many project meetings, members of the committee expressed their preference for individual title deeds. However, it was necessary to meet a variety of infrastructural needs (including road improvements and the provision of public spaces, schools and other public buildings) and to satisfy a range of official standards (for example, the need to maintain a minimum distance from the rivers running through the area, minimum plot size, regulations on access to the road, the percentage of a plot that could be built on). It was clear, therefore, that there was insufficient land for all the resident households to be issued with titles, leading to a request from residents that the KUDP buy additional land to accommodate those displaced by the upgrading.

The initial proposal thus generated a conflict with the Residents' Committee, as members accused the project staff of having already agreed on collective security of tenure, without giving them the opportunity to decide what form of tenure they preferred. This led to pressures to change the project's goal from 'collective security of tenure' to 'appropriate security of tenure', meaning that the question of the form of tenure to be adopted would be decided in consultation with the residents, potentially implying a significant change in the project's objectives.

\subsection{The participatory planning workshop}

After establishing a structure of community governance and commencing work on small infrastructural interventions, the project implementers invited members of the Residents' Committee to attend a workshop outside Kwa-maji. Other workshops had been previously 
organised at critical moments of the project to ensure that important decisions were taken in conjunction with, and had the support of, residents' representatives. However, this was the first workshop to discuss the planning of the settlement, including tenure options.

An important initial discussion during the workshop concerned the ownership of Kwa-maji land. A surveyor explained that the land on which the settlement was located was publicly owned, but that a church had obtained a title deed on some of it. A map was projected on the wall and an animated discussion erupted once those present realised that the title owned by the church indicated an area of land larger than the current site of the church. Following the advice of an officer of the then Ministry of Lands (Lands Officer), it was decided that in order to settle the dispute, the Residents' Committee would write to the Ministry to get the title modified. In other words, the power to cancel land titles was in practice given to the Residents' Committee, whose leaders immediately understood how to use it.

On a previous occasion, the Lands Officer had explained that the land on which Kwa-maji is located was going to be managed by the Steering Committee of the KUDP, with any decision taken by the Committee being ratified ex post by the Ministry of Lands. This message revealed the full power of the Steering Committee with regard to the land assigned to the KUDP. The residents' leaders had strong leverage in the Committee because they could threaten the withdrawal of community support, which was regarded as essential for project success in the context of a conflict-ridden settlement affected by post-election violence.

One of the ways in which workshop facilitators attempted to convince the residents' leaders of the benefits of collective tenure was to explain the constraints on construction imposed by existing by-laws. These were presented by a City Council Officer, moving the workshop 
into a significant negotiation phase. The Officer explained that the minimum plot size for a house was $30 \times 60$ feet. If a plot was smaller, he suggested, it could be used as a store but not as a housing plot. An influential structure-owner proposed that the minimum acceptable plot size be reduced to $30 \times 40$ feet, insisting that the standards need to adapt to the situation, and cleverly mentioning a nearby programme where the City Council had agreed to apply ad hoc standards.

When a government officer reminded the meeting that tenants who had lived in the settlement for more than 10 years were also intended beneficiaries of the land allocation, a structure-owner replied, 'We have plots, we need to formalise [them]', meaning that all that was required was to give structure-owners individual ownership of the plots on which their structures had been built. The Lands Officer reminded the meeting that even this would not be possible, given, for instance, the specified road width of nine metres. A structure-owner's immediate response was to say, 'We don't want roads', indicating extreme reluctance to forfeit any of the land to which the existing structure-owners were laying claim.

Later in the workshop, the residents' representatives were divided into area-based groups for a visioning exercise. When participants were asked to rank the issues and choose the most important, they answered in unison: 'title deeds'. All the groups identified the main solution as the provision of individual title deeds, while some added that the donor should provide additional land on which displaced people could be resettled. Residents' representatives - predominantly structure-owners, as noted above - demonstrated not only that they had a clear agenda, focusing on individual titling to recognise what they considered to be their legitimate property, but also that they had understood how to effectively respond to the implementers by proposing, for instance, to adapt the by-laws to 
the specific circumstances of the settlement. The few tenants attending the workshop did not raise any concerns during this discussion.

Even though Residents' Committee members already had a clear and inflexible view on the type of tenure they wanted, project staff argued that the workshop was only preliminary and would not necessarily determine project decisions. For example, on the subject of negotiating security of tenure, an officer of the Lead Government Agency (LGAO 1), who was interviewed after the workshop, said:

This has to start early, you know it is not one-time thing to go and ask [...] Remember we have various interest groups there: we have landlords who feel they own, I mean the structure-owners who feel they should be allocated the land; we have tenants who really have no claim over the land, they hire out today here, tomorrow the next place; there are the long-term tenants who actually they belong now to [Kwa-maji]; there are the speculators who feel that because they have been in [Kwa-maji] for some time, they should be allocated the land. So the issue of security of tenure is a process, to me this is not [a] one-time decision, so the initial workshop was not for them to make a choice, although they [the residents' representatives] went ahead to jump to the final stage and say "This is what we want", but that choice has not yet been officially made.

In a separate interview, another LGAO (LGAO 2) argued that the area of land available in Kwa-maji was too small to permit the provision of individual titles to both structure-owners and long-term tenants. Instead he argued that, if a Community Land Trust model was adopted, residents would share the land and it would be possible to accommodate them all within the existing settlement area. The LGA, he stressed, was very interested in replicating the STDP model of a Community Land Trust, scaling up the approach in a significantly larger and more challenging settlement in the capital. However, he acknowledged that this could not be accomplished without residents' support and admitted that, if it was not accepted, the alternative was to find the funds to buy additional land to accommodate those displaced from Kwa-maji because, as he recognised, individual tenure would imply that each plot had to satisfy the minimum size requirement, increasing both the area of individual plots and the 
total area required. Clearly, structure-owner members of the Residents' Committee had realised that this option would best serve their interests.

Workshops are a key tool of participatory development practice and there are different views on what happens in these spaces. Two contributions help the analysis of the participatory planning workshop in Kwa-maji, which was one of a series used at crucial stages of the KUDP to obtain 'community' endorsement of the process. Firstly, Cornwall and Coelho (2006) argue that, even when 'invited' by implementers, such participatory spaces can be empowering for participants. In the context of the KUDP, structure-owner members of the Residents' Committee participated in different project activities and as soon as they were given space, underlined what they wanted: individual title deeds. In practice, therefore, they were able to manipulate the participatory space by promoting their preferred solution to the problems of Kwa-maji while satisfying the planners' requirement for community participation. Secondly, Korf (2010) defines the participatory workshop as a 'post-political space of exception [...] where law and [the] political order of the postcolonial state are temporarily suspended' (p. 718), and this was indeed the case in the KUDP. As described above, residents first understood their power when the Lands Officer supported their decision to revoke a title deed held by a church, and this understanding was reinforced when the proposal of a structure-owner that municipal by-laws should be changed to fit participants' needs was acknowledged as legitimate by government implementers. This short account demonstrates how participants in the workshop were able to take important decisions relating to land, bypassing a complex bureaucratic procedure that normally involves multiple levels of authority and politics. In practice, therefore, the workshop was a space in which participants, largely structure-owners, were empowered to nullify laws and circumvent existing democratic structures. It was a new governance arena, which structureowners could influence and try to manipulate in order to promote their own agenda. This 
'new space' was, therefore, certainly empowering, but the question is: empowering for whom? Not all the different interests among residents were fairly represented by the Residents' Committee. Instead, the workshop offered a platform to the structure-owning elite to counter government plans to equitably allocate land to long-term tenants as well as structure-owners. As articulated by Watson (2009), the workshop provided a negotiation space in which implementers' plans were reshaped by the exercise of power by some residents. For project implementers, the community governance structure (the Residents' Committee) was supposed to represent all land users, but in practice it enabled the structure-owners, who considered themselves the 'original community' entitled to land, to assert their claims.

\subsection{Discussing gentrification and the power of structure-owners}

About a month after the planning workshop, the donor organised a roundtable discussion to take stock of the situation and draw out some initial lessons. For the first time, most of the institutional actors involved in the project met without the presence of the residents' representatives and thus the situation of the KUDP with regard to the issues of land tenure and relations between structure-owners and tenants could be openly discussed.

In the context of a discussion on tenure options, the Lands Officer intervened, saying that the Ministry thought that the best option would be sectional titles, whereby residents would 'build and own property together'. However, he added, there was a need for 'a lot of awareness to sell this idea to the community' because 'people want to own something'. The LGAO 1 argued that, 'Maybe we will have a mix of social housing and plots, but [individual] plot allocation must be there. Structure-owners are very powerful and direct most of the 
things'. However, the Lands Officer questioned 'Who are we targeting? $68 \%$ are tenants. ${ }^{7}$ The majority are tenants. Who are we focusing on? Structure-owners... how did they get the land?' At this point, the most senior LGAO present intervened and the following discussion ensued:

Senior LGAO: Regardless of how they [structure-owners] got their land, they are there. There are challenges, there are very rich people inside [Kwa-maji], against this power force you are going to intervene. The intervention is for the poor, but there are the rich. How can we meet the interest of the poor people without compromising the programme? [...]

Local Missionary: In the Residents' Committee more than $60 \%$, maybe even $70 \ldots$ $80 \%$ are structure-owners and they are only $26 \%$ of the people but are determining the fate of the $68 \%$ of the community. They know these things. They know how upgrading programmes work, they [have] had experiences. People who speak for [Kwa-maji] are structure-owners so, even if tenants want high-rise [buildings], they cannot say it. [...]

Officer from another ministry: The objective is to improve the standards of the poor. But the structure-owners who will benefit are people who are economic[ally] stable, not the poor. [...] If you upgrade infrastructures and structure-owners improve houses, the rent will increase and the people will move. Other people will come in but not the targeted poor.

To my knowledge, this was the first time that the key institutional actors had acknowledged and discussed this sensitive topic in a formal meeting. During other events, in which community representatives were present, the conflicting interests of structure-owners and tenants were never directly addressed. Instead, community consent was deemed so important that it forced the development agencies to adopt a 'frontstage' when dealing with 'the community' and to keep their real concerns to a 'backstage'. Because of the adoption of a participatory approach, elected community leaders had been present at most of the meetings, preventing the institutional actors from openly voicing their concerns around the

\footnotetext{
${ }^{7}$ At that stage, the project census data presented earlier were not yet available and actors repeatedly referred to the ratio of tenants/structure-owners (respectively $68 \%$ to $26 \%$ ) found in a sample-based socio-economic survey carried out for the project by a private firm.
} 
need to avoid gentrification and protect tenants. During the discussion in the protected space of the roundtable, they suddenly expressed an understanding that difficult choices would be required to satisfy conflicting needs: on the one hand, maintaining structureowners' support and, on the other, achieving a 'fair' outcome. The solution planned at the project's inception (collective tenure for structure-owners and long-term tenants in order to prevent gentrification) was becoming less and less viable as an option due to the resistance of structure-owners. At the roundtable and in subsequent interviews, project implementers acknowledged that individual titling had to become part of the project. Structure-owners had managed to shape the direction of decisions on how to provide secure tenure.

Staff from the Ministries of Lands and Finance which, at that stage of the project implementation were less involved on the ground and less familiar with the history of the settlement and local power relations than the LGA, had a mainstream view regarding the political economy of land in Nairobi's informal settlements. This view considered structureowners to be illegitimate, associating them with large-scale exploitative landlordship obtained through strong political connections or even directly managed by prominent political figures. This view was based on the seminal work of Amis (1984) in Kibera and other analyses of urban land and politics (e.g. Chege 1981). While it reflects the situation in some settlements, particularly some areas of Kibera, it also leads to overgeneralisation about local land politics in Nairobi's informal settlements, often with little empirical support. For instance, it is an inaccurate representation of Kwa-maji, where the situation is better described by the observation in Syagga et al. (2002) that, in some settlements, many smallscale structure-owners are part of the local community and live in similar socio-economic conditions to their tenants. 
In contrast, after working on the ground in Kwa-maji for almost two years, the LGA was fully aware of how current landlordship had been established as a result of a process of government displacement and relocation in the 1970s and therefore strongly criticised statements about the illegitimacy of structure-owners, presenting a more nuanced position and looking for a compromise between structure-owners' claims and a concern for tenants.

\section{Discussion}

Project implementers in Kwa-maji found themselves having to deal with existing power imbalances within the settlement and had to revise their initial plan to provide all residents with secure tenure through the use of collective title. The choice of tenure system was not a simple technical decision but an intensely political one, which was deeply embedded in local conflicts, three layers of which played out in the negotiations around tenure: first, the existing class conflict between structure-owners and tenants; second, a history of contestations over land, demonstrated by the structure-owners' successful opposition to the previous upgrading project; and third, the wider context of the 2008 post-election violence, which made it politically difficult for any government agency to run the risk of conflict with residents of sensitive areas such as Kwa-maji.

Prior to a detailed discussion, it is important to highlight three sets of urban processes underpinning the case, which are linked to the layers of conflict mentioned above. The first is the particular configuration of Nairobi's informal settlements, characterised by high levels of tenancy, the presence of structure-owners who do not formally own land, and an informal market for structures built on public land. The second relates to urban land and housing market dynamics, which inflate the value of what is at stake in the upgrading process, increasing both the potential for elites to capture substantial value and the risks of market displacement and gentrification. The third process relates to the 
political role of capital cities in Sub-Saharan Africa and how violence in this context can threaten national stability. These sets of processes are also intensified by the overall context of urban growth, which further strains demand for low-income housing and makes land increasingly contested.

In Kwa-maji, the initial idea of the implementers can be conceptualised as institutionalising user rights, as suggested by Boone (2007). Implementers wanted to ratify the on-the-ground situation in such a way that all the existing residents could continue to live in the settlement. The idea was to take the land out of the market by establishing a Community Land Trust managed through an inclusive democratic model which would represent the interests of all the residents. For the implementers, this initially meant that both tenants and structure-owners would be beneficiaries of land regularisation. Boone asserts that securitisation of user rights can protect land users from market forces. This was a central concern for project implementers, given the outcomes of previous projects in Nairobi and the exponential increase in land values at the time, fuelled in the project area by the provision of infrastructure.

However, in practice the power holders in the community asserted their claims over more recent settlers, arguing that only long-term tenants should be included as beneficiaries, should some land remain available. In Boone's terms, Kwa-maji's structure-owners considered themselves to be the 'natural community' whose rights had been conveyed through the informal allocation system since the settlement had come into existence. As an urban area barely settled before the 1970s, they could not utilise a discourse of ancestral ownership. Rather, the 'natural community' was made up of the first people resettled by the municipal authorities from other areas of the city who, although they only had 'temporary permits', had acquired legitimacy over the 30 - 
40 years, even though their claims had not [yet] been recognised by the issue of formal titles.

Initially the project, and particularly the donor, intended to formally recognise the user rights of all residents, which meant that the majority of tenants should also have become land owners. In the rural contexts analysed by Boone, user rights are granted to those who farm the land. In an urban context, this would imply giving the land to those who reside on it, implying the transfer of rights from a minority group of claimants (structure-owners) to the majority (tenants). As Boone predicts, in such circumstances the securitisation of user rights generates conflict. Kwa-maji's history, and particularly the failed upgrading in 2001, demonstrates that attempts at redistribution almost always generate conflict. Such conflict, as Meer (1999) shows, can make projects fail, and was something that implementers in Kwa-maji felt they had to avoid.

Boone (2007) argues that in cases where the securitization of land rights is a redistributive process, it is obvious that the question of whose rights will prevail should be determined at the national level - that is, at the level of the central state' (p. 585). In the context of contested urban land in Nairobi, the choice of whose rights should prevail was determined by local power relations and the inability of the LGA to deal with conflict, particularly in the aftermath of election-related violence and the pre-history of structure-owners' rejection of a previous project. For securitisation to work, Boone suggests, the 'democratic functioning of local land-allocation institutions will have to be founded upon a set of prior, national laws that define the scope of the local community... and principles to guide the political allocation of land' (Boone, 2007, p. 585). In Kwamaji, while the implementers' starting point had defined principles about who should be considered part of the beneficiary community, in practice these had to be negotiated 
with an unbalanced representation of residents, skewed towards the powerful minority of structure-owners.

This minority saw the mechanism of individual titling as supporting their interests. In Kwa-maji, there were, therefore, different narratives/visions on the identity of the legitimate owners of the land, underpinned by different conceptions of who belonged to 'the community'. After initial attempts to design and implement the project as originally conceptualised, implementers developed a realistic understanding of power relations in the area and adopted a pragmatic approach that acceded to the requests of local power holders. The analysis of two project interfaces presented above demonstrates how decisions were influenced by local negotiation and shaped by existing power forces, rather than the policy intentions of the implementers. As Corbridge et al. (2005) and Watson (2009) would argue, the implementation of tenure reforms was shaped by struggles and negotiations in encounters between state implementers and the local elite of structure-owners. Given the limited capacity of African states to implement land reforms, as highlighted by Manji (2001), other locally powerful actors gain importance in determining land reform outcomes. As Boone (2007) suggests, the design and outcomes of land reforms reflect state-society relations: in Kwa-maji the land reforms reflected such relations at the local level. In Kenya, following the devolution of land allocation powers to County Governments under the new Kenya Constitution (Boone 2012), it will be even more difficult to implement land distribution principles agreed at the national level and the ability of local elite actors to influence the local state and capture land reform processes is likely to increase.

Beyond Kenya, this paper demonstrates that, when contentious decisions around the redistribution of key assets are not taken centrally, implementers and groups of local residents may have different views on whose claims to land should be recognised, with 
negotiations over tenure being shaped by and reflecting power relations in a given context. Therefore, context-specific urban land reform outcomes are likely to be shaped by local power relations and the relative power of state and non-state actors involved in the process of detailed planning and implementation rather than land policy decisions taken at higher levels. However, whilst findings from this paper have relevance for urban land reforms, they are of the greatest significance for slum-upgrading processes, which constitute an increasingly important area for urban theory and policy, given the large proportion of urban residents living in informal settlements in the global South.

\section{References}

Amis P (1984) Squatters or tenants: the commercialization of unauthorized housing in Nairobi. World Development 12(1): 87-96.

Bassett EM (2005) Tinkering with tenure: the community land trust experiment in Voi, Kenya. Habitat International 29(3): 375-398.

Bassett EM (2007) The Persistence of the Commons: Economic Theory and Community Decision-Making on Land Tenure in Voi, Kenya. African Studies Quarterly 9(3): 1-29.

Bassett EM and Jacobs HM (1997) Community-based tenure reform in urban Africa: The community land trust experiment in Voi, Kenya. Land Use Policy 14(3): 215-229.

Boone C (2007) Property and constitutional order: Land tenure reform and the future of the African state. African Affairs 106(425): 557-586.

Boone C (2012) Land Conflict and Distributive Politics in Kenya. African Studies Review 55(1): 75-103.

Buckley RM and Kalarickal, J (2006) Land market issues: the mystery of capital revisited. Urban land policy - is titling the answer? In: Buckley RM and Kalarickal J (eds) Thirty Years of World Bank Shelter Lending: Directions in Development Infrastructure. Washington DC: World Bank, pp. 27-38.

Cabannes I (2013) Collective and Communal forms of tenure. Background Paper for the UN Special Rapporteur on Adequate Housing.

Campbell J (1990) World Bank urban shelter projects in east Africa: matching needs with appropriate responses? In: Amis P \& Lloyd PC (eds) Housing Africa's urban poor. Manchester: University Press, pp. 205-223.

Chege M (1981) A tale of two slums: electoral politics in Mathare and Dagoretti, Review of African Political Economy, 8(20): pp. 74-88. 
Corbridge S, Williams G, Srivastava M \& Véron R (2005) Seeing the State: Governance and Governmentality in India. Cambridge: Cambridge University Press.

Cornwall A and Coelho VSP (2006) Spaces for change? The politics of citizen participation in new democratic arenas. London: Zed.

Dafe, F (2009) No Business like Slum Business? The Political Economy of Continued Existence of Slums: A case study of Nairobi. Working Paper Series, Development Studies Institute. London: LSE.

Diacon D, Clarke R and Guimarães S (2005). Redefining the Commons. Coalville, UK, Building and Social Housing Foundation: 55.

Durand-Lasserve, A and Royston L (2002) International Trends and Country Contexts - From Tenure Regularization to Tenure Security. In: Durand-Lasserve A and Royston L (eds), Holding their Ground: Secure Land Tenure for the Urban Poor in Developing Countries. London: Earthscan, pp. 1-26.

Gilbert A (2002) On the mystery of capital and the myths of Hernando de Soto: What difference does legal title make? International Development Planning Review 24(1): 1-19.

Gilbert A (2008) Viewpoint: Slums, tenants and home-ownership: on blindness to the obvious. International Development Planning Review 30(2): i-x.

Government of Kenya (2004) Sessional Paper No. 3 on National Housing Policy for Kenya, Nairobi.

Government of Kenya (2008) Final Report of the Commission of Inquiry into the Post Election Violence (Waki Report), Nairobi.

Gulyani S and Bassett EM (2007) Retrieving the baby from the bathwater: slum upgrading in Sub-Saharan Africa. Environment and Planning C: Government \& Policy 25(4): 486515.

Gulyani S and Talukdar D (2008) Slum Real Estate: The Low-Quality High-Price Puzzle in Nairobi's Slum Rental Market and its Implications for Theory and Practice. World Development 36(10): 1916-1937.

Gupta A (1995) Blurred Boundaries: The Discourse of Corruption, the Culture of Politics, and the Imagined State. American Ethnologist 22(2): 375-402.

Huchzermeyer M (2008) Slum Upgrading in Nairobi within the Housing and Basic Services Market. Journal of Asian and African studies 43(1): 19-39.

Joireman SF (2011) Where there is no government: enforcing property rights in common law Africa. Oxford: Oxford University Press.

K'Akumu OA and Olima WHA (2007) The dynamics and implications of residential segregation in Nairobi. Habitat International 31(1): 87-99.

Korf B (2010) The Geography of Participation. Third World Quarterly 31(5): 709-720.

Kumar S (2011) The research policy-dialectic. City 15(6): 662-673.

Leach A (2000) Land Reform and Socio-Economic Change in Kenya. In: Wanjala SC (ed), Essays on Land Law. The Reform Debate in Kenya. Nairobi: Faculty of Law, University of Nairobi, pp. 192-225.

Long N (2001) Development sociology: actor perspectives. London; New York: Routledge.

Manji A (2001) Land Reform in the Shadow of the State: The Implementation of New Land Laws in Sub-Saharan Africa. Third World Quarterly 22(3): 327-342.

Marx C (2009) Conceptualising the potential of informal land markets to reduce urban poverty. International Development Planning Review 31(4): 335-353. 
Meer S (1999) Constraints to land reform and gender equity goals. Agenda 15(1): 71-88.

Mitullah W (1992) State policy \& urban housing in Kenya: the case of low income housing in Nairobi. IDS (Nairobi) Working Paper 485. Nairobi: IDS.

Musembi CN (2007) De Soto and land relations in rural Africa: breathing life into dead theories about property rights. Third World Quarterly 28(8): 1457-1478.

Ochieng CC (2007) Affordability of Low Income Housing in Punwani, Nairobi, Kenya. International Journal of Architectural Research 1(2): 35-44.

Payne G, Durand-Lasserve A and Rakodi C (2009) The limits of land titling and home ownership. Environment and Urbanization 21(2): 443-462.

Platteau JP (2004) Monitoring Elite Capture in Community-Driven Development. Development and Change 35: 223-246.

Rakodi C (1995) Rental Tenure in the Cities of Developing Countries. Urban Studies 32(4-5): 791-811.

Rakodi C (2001) Forget planning, put politics first? Priorities for urban management in developing countries. International Journal of Applied Earth Observation and Geoinformation 3(3): 209-223.

Rakodi C (2006) Social agency and state authority in land delivery processes in African cities: Compliance, conflict and cooperation. International Development Planning Review 28(2): 263-285.

Rigon A (2013) Fragmentation and Democratic Transformations in Kenya: Ethnicity as an Outcome Rather Than a Cause (1992-2013). ISPI Studies 170:1-10.

Rigon A (2014) Building Local Governance: Participation and Elite Capture in Slum-upgrading in Kenya. Development and Change 45: 257-283.

Rolnik R (2013) Report of the Special Rapporteur on adequate housing as a component of the right to an adequate standard of living, and on the right to non-discrimination in this context, Raquel Rolnik. Human Rights Council, $25^{\text {th }}$ Session.

Rossi B (2004) Revisiting Foucauldian Approaches: Power Dynamics in Development Projects. Journal of Development Studies 40: 1-29.

Soto Hd (1989) The other path: the invisible revolution in the Third World. London: Tauris.

Soto Hd (2000) The mystery of capital: why capitalism triumphs in the West and fails everywhere else. London: Bantam.

Southall R (2005) The Ndungu Report: Land \& Graft in Kenya. Review of African Political Economy 32(103): 142-151.

Syagga P, Mitullah W and Karirah-Gitau S (2001) Nairobi Situation Analysis. Consultative Report. Nairobi: UN-Habitat \& Government of Kenya.

Syagga P, Mitullah W and Karirah-Gitau, S (2002) A rapid economic appraisal of rents in slums and informal settlements. Nairobi: UN-Habitat \& Government of Kenya.

Satterthwaite D (2009) Getting land for housing; what strategies work for low-income groups? Environment and Urbanization 21: 299-307.

Tuts R (1996) Cost modelling for appropriate building and planning standards in Kenya. Habitat International 20(4): 607-623.

Watson V (2009) Seeing from the South: Refocusing Urban Planning on the Globe's Central Urban Issues. Urban Studies 46(11): 2259-2275. 
